Journal of Islamic Economics and Finance Studies

\title{
Analisis Perilaku Konsumen, Produsen, dan Pasar dalam Islam pada Masyarakat
}

\author{
Riani Nur Aini \\ Institut Agama Islam Negeri Ponorogo \\ Rianinuraini123@gmail.com
}

Received: September 27, 2020 | Accepted: November 23, 2020 | Published: November 25, 2020

\begin{abstract}
Islam is a complete, universal and dynamic system of life in regulating human life, inclubing Islamic rules in regulating consumer behavior, production and markets. This provision is left to the natural mechanism. Consumer behavior is an action or process carried out by someone to search for, buy, use, evaluate, and spend the products and services that they hope will satisfy their needs. Consumer behavior can influence the number of requests and needs. Producer behavior is an activity of regulating production so that the products produced are of high quality so that they can make a profit. This producer behavior can effect the amount of production and supply of goods or services. Market behavior is a habitual patters of the market including the decision making process as well as individual and organizational activities on certain products. In Islam these three behaviors must be grounded according to Islamic teachings namely monotheism, justice, nubuwah, khalifah and ma'ad. It aims to bring benefits and benefit to the community and achieve blessings from Allah swt.
\end{abstract}

Keywords: consumer behavior, producers, markets

\begin{abstract}
Abstrak
Islam adalah sistem hidup yang lengkap, universal dan dinamis dalam mengatur kehidupan manusia, termasuk kaidah Islam dalam mengatur tentang harga dan mekanisme pasar. Ketentuan harga itu diserahkan kepada mekanisme pasar yang alamiah. Sistem Islam menolak menetapkan harga oleh penguasa, karena Allah-lah yang menentukannya. Harga yang terbentuk harus sesuai dengan kekuatan penawaran (suplay) dan permintaan (demand) pasar. Olehnya itu harga barang tidak boleh ditetapkan oleh pemerintah, karena ketentuan harga tergantung pada hukum supply and demand. Sistem Islam sangat mendorong harga yang adil dengan mendorong persaingan pasar yang sempurna. Untuk memenuhi harga yang adil perlu adanya moralitas (fair play), kejujuran (honesty), keterbukaan (transparancy) dan keadilan (justice) serta menghindari segala macam bentuk spekulasi. Jika nilai-nilai ini ditegakkan, maka tidak ada alasan untuk menolak harga pasar. Sistem ekonomi Islam masih memberikan peluang pada kondisi tertentu untuk melalukan intervensi harga (price intervention) oleh pemerintah bila terjadi distorsi pasar, baik yang disebabkan oleh faktor alamiah maupun perilaku menyimpang dari pelaku pasar.
\end{abstract}

Kata kunci: Perilaku Konsumen,Perilaku produsen, Pasar 


\section{PENDAHULUAN}

Manusia memiliki kebutuhan hidup yang jauh lebih banyak, baik dalam jenis, jumlah maupun kualitas yang mereka inginkan (Huda,2007:2). Keinginan untuk memenuhi kebutuhan hidup merupakan naluri manusia (Nasutiaon 2006:53). Kebutuhan manusia adalah segala sesuatu yang diperlukan agar manusia berfungsi secara sempurna, berbeda dan lebih muliadari pada makhluk-makhluk lainnya, misalnya, baju sebagai penutup aurat, sepatu sebagai pelindung kaki, dan sebagainya. Sedangkan keinginan adalah terkait dengan hasrat atau harapan seseorang yang jika dipenuhi belum tentu akan meningkatkan kesempurnaan fungsi manusia ataupun barang. Keinginan terkait dengan suka atau tidak sukanya seseorang terhadap suatu barang/jasa, dan hal ini bersifat subjektif tidak bisa dibandingkan antar satu orang dengan orang lain (P3EI,2008,130).

Perilaku konsumen adalah tindakan yang langsung terlibat dalam mendapatkan, mengkonsumsi dan menghabiskan produk dan jasa, termasuk keputusan yang mendahului dan menyusul tindakan ini.

Produksi adalah sebuah proses yang telah terlahir di muka bumi ini semenjak manusia menghuni planet ini. Produksi sangat prinsip bagi kelangsungan hidup dan juga peradaban manusia dan bumi. Sesungguhnya produksi lahir dan tumbuh dari menyatunya manusia dengan alam. Kegiatan produksi merupakan mata rantai dari konsumsi dan distribusi. Kegiatan produksilah yang menghasikan barang dan jasa, kemudian dikonsumsi oleh para konsumen. Tanpa produksi maka kegiatan ekonomi akan berhenti, begitu pula sebaliknya. Untuk menghasilkan barang dan jasa kegiatan produksi melibatkan banyak faktor produksi. Fungsi produksi menggambarkan hubungan antar jumlah input dengan outp huut yang dapat dihasilkan dalam satu waktu periode.

Pasar secara umum adalah sarana atau tempat bertemunya penjual dengan pembeli, baik itu secara langsung maupun tidak langsung, guna melakukan aktivitas transaksi jual beli. Pasar memiliki fungsi yang penting dalam perekonomian suatu negara meskipun sering terjadi kecurangan dan ketidakadilan di dalam pasar terutama masalah harga. Oleh karena itu terdapat sejumlah aturan tentang pembentukan harga dan transaksi yang terjadi di pasar. Aturan tersebut sering kita namakan dengan mekanisme pasar yaitu proses penentuan harga berdasarkan dari kekuatan permintaan dan penawaran. Mekanisme pasar merupakan suatu sistem yang cukup efisien dalam mengalokasikan berbagai faktor produksi dan mengembangkan perekonomian, tetapi dalam keadaan tertentu dapat menimbulkan akibat yang buruk, sehingga dibutuhkan campur tangan dari pemerintah untuk memperbaikinya. 


\section{TINJAUAN PUSTAKA}

\section{A. Perilaku Konsumen}

Perilaku konsumen adalah suatu tindakan yang langsung terlibat dalam mendapatkan, mengkonsumsi dan menghabiskan produk dan jasa, termasuk keputusan yang mendahului dan menyusul tindakan ini (James \& Angel, 1994).

Perilaku konsumen menurut Loudon dan Bitta yang dikutip oleh Bilson Simamora dalam bukunya "panduan riset perilaku konsumen" lebih menekankan perilaku konsumen yaitu sebagai suatu proses pengambilan keputusan (Simamora, 2002: 4).

Teori perilaku konsumen (customer behavior) mempelajari bagaiman manusia memilih diantara berbagai pilihan yang dihadapi dengan memanfaatkan sumber daya yang dimilkinya (Nasution, 2011: 33).

Islam melihat aktivitas ekonomi adalah salah satu cara untuk menciptakan maslahah menuju falah yaitu kebahagiaan dunia dan akhirat. Motif konsumsi ini pada dasarnya adalah maslahah. Meskipun secara alami motif dan tujuan berkonsumsi (aktivitas ekonomi) dari seseorang individu adalah untuk mempertahankan hidupnya (Karim, 2012).

Sesungguhnya Islam tidak mempersulit jalan hidup seorang konsumen, hal ini terbukti apabila seseorang mendapatkan penghasilan dan setelah dihitung hanya dapat memenuhi kebutuhan pribadi dan keluarga saja, maka tidak ada keharusan baginya untuk mengeluarkkan konsumsi sosial. Akan tetapi, bagi seseorang yang pendapatannya lebih banyak maka Islam menganjurkan memberikan sebagian dari hartanya kepada orang-orang yang membutuhkan.

Islam mengajarkan bahwa manusia selama hidupnya akan mengalami tahapantahapan dalam kehidupannya yaitu tahapan dunia dan akhirat. Oleh karena itu, Islam mengajarkan kepada umatnya untuk selalu mencapai kebahagiaan dunia dan akhirat. Hal ini berarti saat seseorang melakukan konsumsi ia harus memiliki nilai antara dunia dan akhirat. Dengan demikian maka yang lebih diutamakan adalah konsumsi untuk dunia atau konsumsi untuk akhirat (Muhammad, 2004:173).

Dengan demikian Jadi, perilaku konsumen muslim yaitu suatu aktivitas manusia yang berkaitan dengan dengan aktivitas membeli dan menggunakan produk barang dan jasa, dengan memperhatikan kaidah-kaidah ajaran Islam, dan berguna bagi kemaslahatan umat. Yang dimaksud yaitu dalam mengkonsumsi, menyimapan, mengelola, dan memilih barang atau jasa dengan cara yang halal lagi baik, merupakan hal-hal yang sangat diagungkan pembalasannya, dan akan dikabulkan doan-doanya (Simamora, 2002: 4).

Sebagaimana hadits yang diriwayatkan Imam Muslim yang menyatakan (Ahmad Tu'ilab, 201-203): 
"Hai manusia! Sesungguhnya Allah itu baik, tidak akan menerima (sesuatu) kecuali yang baik (pula), dan sesungguhnya Allah itu memerintahkan orang-orang beriman sebagaimana Dia memerintahkannya kepada para rasul (dahulu)". (HR. Muslim).

Di dalam perilaku konsumen itu ada beberapa istilah diantaranya:

\section{Pemintaan}

Permintaan adalah sejumlah barang yang diinginkan untuk dibeli untuk memenuhi kebutuhan pada berbagai tingkat i dan waktu tertentu di pasar (Lukman, 2007: 18). Hukum permintaan yaitu " ketika harga suatu barang atau jasa mengalami penurunan maka jumlah permintaan akan naik, dan sebaliknya ketika harga meningkat maka jumalah barang atau jasa yang diminta akan berkurang". Faktorfaktor yang mempengaruhi permintaan:

a. Harga barang itu sendiri

b. Pendapatan masyarakat

c. Intensitas kebutuhan

d. Jumlah penduduk

e. Selera

2. Kebutuhan

Kebutuhan manusia banyak dan beraneka ragam, bahkan tidak hanya beraneka ragam tetapi akan bertambah terus menerus tidak ada habisnya, sejalan dengan perkembangan peradaban dan kemajuan ilmu pengetahuan dan teknologi. Satu kebutuhan telah anda penuhi, tentu akan datang lagi kebutuhan yang lainnya. Kebutuhan adalah keinginan manusia tehadap barang dan jasa yang harus dipenuhi, dan jika tidak dipenuhi akan berpengaruh terhadap keberlangsungan hidupnya atau bisa menimbulkan dampak negatif. Contoh nya minum obat bagi orang yang sakit, makan nasi bagi orang yang lapar. Hal ini disebut sebagai kebutuhan karena apabila tidak dipenuhi maka akan menimbulkan dampak negatif seperti sakitnya bertambah parah atau bahkan bisa saja meninggal atau kondisi tubuh tidak nyaman akibat rasa lapar (Rochmawati, 2008:4).

Sesuai dengan fitrah manusia, kebutuhan manusia itu tidak terbatas, baik jumlah maupun juga macamnya. Hal ini disebabkan oleh beberapa faktor berikut ini:

a. Karena kodrat manusia

b. Faktor alam dan lingkungan

c. Faktor lingkungan masyarakat

d. Faktor perdagangan internasional

e. Faktor demonstracy effect

Islam tidak pernah melupakan unsur materi dalam memakmurkan dan meningkatkan taraf hidup manusia, berikut dalam Islam mengenai konsumsi itu dikendalikan oleh lima prinsip (Manan, 1997:50): 

a. Keadilan
b. Kebersihan
c. Kesederhanaan
d. Kemurahan hati
e. moralitas

3. Ciri-ciri Perilaku Konsumen Islam

a. Seorang muslimah dalam berkonsumsi didasarkan atas pemahaman bahwa kebutuhannya sebagai manusia terbatas. Seorang akan mengkonsumsi pada tingkat wajar dan tidak berlebihan. Tingkat kepuasan itu pada kebutuhan bukan pada keinginan.

b. Tingkat kepuasan tidak hanya ditentukan oleh jumlah satu atau dua pilihan, namun tingkat kepuasan akan ditentukan oleh kemaslahatan yang dihasilkan.

c. Seorang muslim atau muslimah tidak akan mengonsumsi barang-barang yang sifatnya tidak jelas apalagi barang-barang yang sudah jelas ada unsur haramnya.

d. Seorang muslim atau muslimah tidak akan membelanjakan hartanya secara berlebihan, dan tidak akan membeli barang-barang di luar batasan atau jangkauannya.

e. Sebagai seorang muslim atau muslimah akan mencapai tingkat kepuasannya itu tergantung kepada rasa syukurnya.

\section{Etika Dalam Berkonsumsi}

Untuk memenuhi kebutuhan hidupnya konsumen yang dilakukan oleh seorang muslim akan sangat erat hubungannya dengan etika dan norma dari konsumsi itu sendiri. Menurut pendapat Naqfi setidaknya terdapat 6 aksioma pokok dalam konsumsi, yaitu:

a. Tauhid (unity/ kesatuan).

Aksioma ini mempunyai 2 kriteria yaitu yang pertama rabbaniyah gayah (tujuan), dan wijhah (sudut padang). Kriteria yang pertama yaitu mencapai maqam ridhoNya. Sehingga pengabdian kepada Allah adalah cita-cita akhir. Kriteria yang kedua adalah rabbaniyah masdar (sumber hukum) dan manhaj (sistem) yang mana kriteria ini merupakan suatu system yang ditetapkan untuk mencapai sasaran yang pertama dengan sumber Al-Quran dan Al-Hadist.

b. Kehendak yang bebas (Ikhtiyar)

Kehendak bebas merupakan kontribusi Islam yang paling Orisinil dalam filsafat social tentang konsep "manusia " bebas". Hanya Tuhan yang bebas, namun dalam batas-batas skema penciptaannya, manusia juga secara relative juga memiliki kebebasan. Manusia diberi kebebasan untuk membimbing kehidupannya di muka bumi (Muhammad dkk, 2002: 15) 
c. Halal

Islam membatasi kebebasan dari kehendak dengan hanya mengkonsumsi barang yang halal yang menunjukkan nilai kebaikan, kesucian keindahan serta menimbulkan maslahah yang paling optimal.

d. Sederhana

Hal yang paling penting yang harus dijaga dalam berkonsumsi adalah menghindari sifat boros dan melampaui batas sehingga, israh dilarang dalam Islam (Sumarin, 2013: 94).

5. Faktor-faktor yang Mempengaruhi Perilaku Konsumen

Ada beberapa faktor utama yang mempengaruhi perilaku konsumen dalam hal pembelian suatu barang atau jasa, yaitu:

a. Faktor Kebudayaan

Budaya mengacu pada seperangkat nilai, gagasan, artefak, dan simbol bermakna lainnya yang membantu individu berkomunikasi, membuat tafsiran, dan melakukan evaluasi sebagai anggota masyarakat (Angel.1994:184).

b. Faktor Sosial

1) Keluarga

Keluarga dalam budaya yang cenderung kolektif sangat menentukan perilaku, pilihan produk dan aktifitas pembelian. Dari keluarganya konsumen belajar dan bersosialisasi untuk menjadi konsumen kelak di kemudian hari.

2) Kelompok acuan

Seseorang yang terdiri dari semua kelompok, yang memiliki pengaruh langsung (tatap muka) atau tidak langsung terhadap sikap atau perilaku seseorang.

3) Peran dan status

Posisi seseorang dalam tiap kelompok dapat ditentukan dari segi peran dan status. Tiap peran itu memiliki arti penting yaitu membawa status yang mencerminkan penghargaan umum oleh masyarakat.

c. Faktor Pribadi

1) Usia dan tahap siklus hidup

Orang akan mengubah barang dan jasa yang mereka beli sepanjang kehidupan mereka. Kebutuhan dan selera seseorang akan berubah sesuai dengan usia.

2) Pekerjaan

Setiap orang memiliki cita-cita tertentu tentang pekerjaannya. Namun, banyak yang tidak dapat merealisasikan cita-cita itu. Orang itu bisa bekerja sesuai dengan cita-citanya atau tidak, namun yang jelas ia memerlukan barang-barang yang sesuai pekerjaannya. 


\section{3) Gaya hidup}

Secara sederhana, seperti yang dikatakan Rhenald Kasali (2001), gaya hidup adalah bagaimana orang yang menghabiskan waktu dan uangnya. Artinya, pemasar bisa menganalisis gaya hidup seseorang dari bagaimana orang itu beraktivitas yaitu menjalankan tuntutan pekerjaannya, memenuhi hasratnya untuk melakukan berbagai hobinya, berbelanja, maupun melakukan olah raga kegemarannya ataupun kegiatan yang lainnya.

\section{B. Perilaku Produsen}

Produsen adalah orang atau suatu badan perusahaan yang berperan dalam menaikan nilai guna suatu barang atau jasa sehingga dapat menghasilkan barang konsumsi untuk memenuhi kebutuhan konsumen. Namun dalam perilaku produsen, tidak hanya kegiatan produksi yang dijalani tetapi banyak proses lain yang harus dijalani agar tercapai tujuan dari perusahaan tersebut, antara lain yaitu menghitung berapa maksimal barang yang dapat dihaslikan atau diproduksi dengan biaya semaksimal mungkin sehingga akan terjadi keuntungan maksimal dalam perusahaan.

Teori perilaku produsen adalah suatu teori yang menjelaskan tentang bagaimana tingkah laku produsen dalam menghasilkan produk yang selalu berupaya untuk mencapai efesiensi dalam kegiatan produksinya. Produsen berusaha untuk menghasilakn produksi sebanyak mungkin dengan mengatur penggunaan factor produksi yang paling efisien. Di dalam produsen itu terdapat:

\section{Produksi}

Produksi adalah kegiatan mengubah suatu bahan baku atau sumber daya alam menjadi suatu barang yang dapat berguna bagi konsumen sehingga menaikkan nilai jual dan nilai guna barang tersebut.

Dalam teori produksi memberikan penjelasan tentang perilaku produsen yang memaksimalkan keuntungannya maupun mengoptimalkan efisiensi produksinya. Dimana Islam mengakui kepemilikan prinadi dalam batas-batas tertentu.

Dalam kegiatan produksi terjadi proses perubahan bentuk atau perubahan nilai guna barang atau jasa, setelah proses selesai kemudian akan muncul outputnya yaitu suatu barang atau jasa yang bisa dijual atau dipasarkan kepada distributor untuk didistribusikan kepada konsumen atau dari produsen langsung didistribusikan kepada konsumennya.

2. Penawaran

Penawaran diartikan sebagai keseluruhan jumlah barang dan jasa yang ditawarkan dalam berbagai kemungkinan harga yang berlaku di pasar dalam periode tertentu (Ahman,2009: 98-99). Hukum penawaran " ketika harga suatu barang meningkat maka jumlah penawarannya akan meningkat, dan juga sebaliknya ketika harga suatu barang menurun maka jumlah penawarannya ikut menurun juga (Rahardja,2008: 36). 
Fungsi penawaran terjadi dari perilaku produsen yang menginginkan keuntungan maksimum dengan kendala biaya produksi tertentu (Ahman,2009: 88). Faktor yang mempengaruhi penawaran (Ahman,20019: 99-100):

a. Biaya produksi

b. Teknologi

c. Harapan akan harga masa depan

d. Tujuan perusahaan

e. Pajak

f. Prediksi/perkiraan

\section{Pasar}

Berdagang adalah suatu aktivitas umum yang di lakukan di pasar, pasar adalah tempat bertemunya penjual dan pembeli untuk melakukan transaksi jual beli atau jasa, menurut ilmu ekonomi pasar itu berkaitan dengan kegiatanya bukan tempatnya, walaupun Islam mendorong perdagangan sebagai pendorong terciptanya pasar (Huda, 2015:69).

Konsep makanisme pasar dalam Islam dapat dirujuk kepada hadis Rasululllah saw sebagaimana disampaikan oleh Anas ra, sehubungan dengan adanya kenaikan harga-harga barang di kota Madinah. Sabda Rasulullah saw yang artinya:

Dari Anas ibn Malik ra. Berkata: Harga komoditas perdagangan beranjak naik pada zaman Rasulullah saw, lalu para sahabat mengadu kepadabeliau seraya berkata: "Ya Rasulullah, harga barang-barang menjadi mahal, maka tetapkanlah patokan harga buat kami. Lalu Rasulullah saw menjawab: Sesungguhnya Allah lah yang menetapkan harga (Zat) Yang menahan dan yang membagikan rizki, dan sesungguhnya saya berharap agar dapat berjumpa dengan Allah swt dalam kondisi tidak seorangpun di antara kalian yang menuntut saya karena kedzaliman yang menimbulkan pertumpahan darah dan harta."

Inilah adalah teori ekonomi Islam mengenai harga. Rasulullah saw. dalam hadis tersebut tidak menentukan harga. Ini menunjukkan bahwa ketentuan harga itu diserahkan kepada mekanisme pasar yang alamiah. Rasulullah saw. menolak tawaran itu dan mengatakan bahwa harga di pasar tidak boleh ditetapkan, karena Allah-lah yang menentukannya. Ucapan Nabi Saw itu mengandung pengertian bahwa harga pasar itu sesuai dengan kehendak Allah swt yang sunnatullah atau sesuai hukum supply and demand.

Jawaban Rasulullah atas kenaikan harga menunjukkan bahwa seorang penguasa atau pemerintah tidak boleh melakukan intervensi terhadap masalah harga, yang menentukan kenaikan atau penurunan harga adalah Allah yaitu terkait dengan sunnatullah dari Allah misalnya musibah, paceklik, panen raya serta keadaan ekonomi setiap individu atau masyarakat. Tingkat harga sesuai sunnatullah sesuai dengan tingkat permintaan (demand) dan penawaran (supply). Sehingga dalam 
mekanisme pasar Islam semua pihak dapat menikmati harga secara adil dan secara manusiawi atau fitrah tidak terbantahkan setiap manusia.

Dalam pasar terdapat bentuk-bentuk pasar yaitu (nuraini,2003: 118-119):

1. Pasar persaingan sempurna

Suatu kondisi dimana pasar tersebut terdapat banyak penjual dan banyak pembeli.

2. Pasar Monopoli

Pasar ini merupakan situasi pasar dimana hanya ada satu penjual produk dan produk itu tidak ada penggantinnya.

3. Pasar Oligopoli

Pasar ini merupakan pasar yang mempunyai unsur persaingan sempurna dan monopoli atau bisa disebut dengan bentuk menengah. Bentuk tersebut salah satunga pasar Oligopoli.

4. Pasar Persaingan Monopolistik

Bentuk pasar ini merupasan bentuk pasar menengah lainnya selain oligopoli. Pasar persaingan monopolistic ini merupakan perpaduan antara bentuk persaingan sempurna dengan monopoli.

Faktor-Faktor Yang Mempengaruhi Harga Dalam Islam

1. Ketersediaan Barang ( supply)

Ketersedian barang/jasa dalam pasar akan memudahkan masyarakat untuk memenuhi kebutuhannya, sehingga harga secara relative senantiasa akan berada dalam keseimbangan. Dan sebaliknya kelangkaan akan mendorong spekluasi yang bisa berakibat pada kenaikan harga. Menurut Ibnu Khaldun : Ketika barang-barang yang tersedia sedikit, harga-harga akan naik, Namun, bila jarak antar kota dekat dan aman untuk melakukan perjalanan, akan banyak barang yang diimpor sehingga ketersediaan barang akan melimpah, dan hargaharga akan turun.

2. Rekayasa Demand (ba'i Najasy)

Produsen menyuruh pihak lain memuji produknya atau menawar dengan harga tinggi, sehingga calon pembeli yang lain tertarik untuk membeli barang dagangannya. Najasy dilarang karena dapat menaikkan harga barang-barang yang dibutuhkan oleh para pembeli.

3. Rekayasa suplay (ba'i ikhtikar)

Mengambil keuntungan di atas keuntungan normal dengan cara menahan barang untuk tidak beredar di pasar supaya harga-nya naik.

4. Tallaqi Al-rukban

Praktek ini dengan cara mencegat orang-orang yang membawa barang dari desa dan membeli barang tersebut sebelum tiba di pasar. Rasulullah saw melarang praktek semacam ini dengan tujuan untuk mencegah terjadinya kenaikan harga. Bagian ini secara berurutan sebaiknya menguraikan latar 
belakang secara umum, kajian literatur (state of the art) sebagai dasar untuk menegaskan kebaruan naskah tulisan, pernyataan posisi penulis di antara diskursus akademik, serta pertanyaan (penelitian) atau hipotesis (proposisi) yang ingin 12didiskusikan dalam naskah tulisan ( Khaldun, 1967).

\section{METODE PENELITIAN}

Metode penelitian yang digunakan yaitu metode penelitian kualitatif dan penelitian kuantitatif. Metode penelitian kualitatif merupakan sebuah penelitian yang menekankan analisis proses berfikir secara induktif yang berkaitan dengan dinamika hubungan antar fenomena yang diamati, dan senantiasa menggunakan logika ilmiah (Gunawan, 2013:80). sedangkan metode penelitian kuantitatif yaitu metode penelitian yang spesifikasinya adalah sistematis, terencana,dan truktual dengan jelas sejak awal hingga pembuatan desain penelitiannya. Metode ini merupakan metode yang banyal menuntut penggunaan angka, mulai dari pemngumpulan data, penafsiran terhadap dat, erta penampilan dari hasil penelitian tersebut.

\section{HASIL DAN PEMBAHASAN}

\section{A. Perilaku Konsumen}

Tabel 1. Data Kebutuhan konsumen

\begin{tabular}{lllll}
\hline No & Kelompok & \multicolumn{1}{c}{ Jenis Barang } & \multicolumn{1}{c}{$\begin{array}{c}\text { Harga Satuan } \\
\text { (Rp) }\end{array}$} & Harga Grosir (Rp) \\
\hline 1. & Sayuran & Bawang Merah & $36.333 / \mathrm{kg}$ & $254.331 / 7 \mathrm{~kg}$ \\
& & Tomat & $9.667 / \mathrm{kg}$ & $38.668 / 4 \mathrm{~kg}$ \\
& & Cabe Rawit Merah & $21.000 / \mathrm{kg}$ & $105.000 / 5 \mathrm{~kg}$ \\
\hline 2. & Bahan Pokok & Beras & $10.333 / 15 \mathrm{~kg}$ & $154.995 / 15 \mathrm{~kg}$ \\
& & Minyak Bimoli & $11.500 / \mathrm{L}$ & $103.500 / 9 \mathrm{~kg}$ \\
& & Gula & $17.500 / \mathrm{kg}$ & $140.000 / 8 \mathrm{~kg}$ \\
\hline 3. & Pakaian & Baju & $58.000 / \mathrm{pcs}$ & $696.000 / 12 \mathrm{pcs}$ \\
& Celana panjang & $70.000 / \mathrm{pcs}$ & $630.000 / 9 \mathrm{pcs}$ \\
& Rok & $62.000 / \mathrm{pcs}$ & $310.000 / \mathrm{pcs}$ \\
& & & &
\end{tabular}

Sumber: Hasil dari Penelitian 
1. Hasil wawancara

Tabel 2. Hasil wawancara

\begin{tabular}{|c|c|}
\hline Pertanyaan & Jawaban \\
\hline $\begin{array}{l}\text { Jelaskan bagaimana mekanisme harga } \\
\text { yang diterapkan pada harga jual } \\
\text { kepada konsumen yang ada dipasar? }\end{array}$ & $\begin{array}{l}\text { Untuk harga ini sendiri berasal dari } \\
\text { produsen. Contohnya harga minyak dari } \\
\text { produsen } 11.500 / \mathrm{kg} \text { nanti si penjual } \\
\text { tidak boleh menjual dibawah } 11.500 / \mathrm{kg} \text {. } \\
\text { karena jika dibawahnya maka penjual } \\
\text { mengalami kerugian. Jadi, semua harga } \\
\text { pokok bersala dari produsen. }\end{array}$ \\
\hline $\begin{array}{l}\text { Apakah ada perubahan harga yang } \\
\text { terjadi ? dan apakah perubahan } \\
\text { tersebut bisa merugikan satu pihak? }\end{array}$ & $\begin{array}{l}\text { Perubahan harga ini terjadi karena } \\
\text { perubahan harga ditentukan oleh } \\
\text { penjual dan pembeli. Namun, tidak } \\
\text { merugikan salah satu pihak. }\end{array}$ \\
\hline Apakah ada perubahan harga pasar? & $\begin{array}{l}\text { Perubahan harga pasar bisa terjadi } \\
\text { karena adanya perbedaan musim atau } \\
\text { adanya waktu tertentu. Seperti bulan } \\
\text { ramadhan harga akan mulai naik karena } \\
\text { banyaknya permintaan dan minimnya } \\
\text { stock barang yang ada. }\end{array}$ \\
\hline
\end{tabular}

Sumber: Hasil dari Penelitian

B. Perilaku Produsen

1. Data

Tabel 3. Data produksi

\begin{tabular}{lclll}
\hline No & Produksi ke- & $\begin{array}{l}\text { Jumlah } \\
\text { Produksi }\end{array}$ & $\begin{array}{l}\text { Harga Per } \\
\text { Unit (Rp) }\end{array}$ & HPP \\
\hline 1 & 1 & $\begin{array}{l}100 \\
\text { bungkus }\end{array}$ & 3000 & 2000 \\
\hline 2 & 2 & $\begin{array}{l}120 \\
\text { bungkus }\end{array}$ & 3000 & 2000 \\
\hline 3 & 3 & 90 bungkus & 3000 & 2.000 \\
\hline 4 & 4 & $\begin{array}{l}150 \\
\text { bungkus }\end{array}$ & 3000 & 2.000 \\
\hline
\end{tabular}

Sumber: Hasil dari Penelitian 
Tabel 4. Data perlengkapan

\begin{tabular}{lllll}
\hline No & Nama Input & Jumlah & $\begin{array}{c}\text { Harga Per Unit } \\
(\mathbf{R p})\end{array}$ & Umur Ekonomis \\
\hline 1 & Wajan & 1 & 140.000 & 11 bulan tahun \\
\hline 2 & Pisau & 1 & 7.000 & 3 bulan \\
\hline 3 & Wadah & 2 & 18.000 & 3 bulan \\
\hline 4 & Mixer & 1 & 180.00 & 10 bulan \\
\hline 5 & Erok+ sotel & 1 & 25.000 & 8 bulan \\
\hline
\end{tabular}

Sumber: Hasil dari Penelitian

Tabel 5. Data bahan

\begin{tabular}{|c|c|c|c|c|}
\hline No & $\begin{array}{l}\text { Produksi } \\
\text { ke- }\end{array}$ & Jumlah & $\begin{array}{l}\text { Harga Per Unit } \\
\text { (Rp) }\end{array}$ & $\begin{array}{c}\text { Jumlah Tahapan } \\
\text { Per Produksi }\end{array}$ \\
\hline \multirow[t]{8}{*}{1} & 1 & Tepung & 10.000 & $3 \mathrm{~kg}$ \\
\hline & & Telur & 2. 000 & 13 butir \\
\hline & & Gula & 15.000 & 12 sendok \\
\hline & & Kentang & 12.000 & $1 \mathrm{~kg}$ \\
\hline & & Margarin & 8.000 & 400 gram \\
\hline & & Garam & 1.000 & 5 sendok the \\
\hline & & Farmipan & 2.000 & 4 sendok teh \\
\hline & & $\begin{array}{l}\text { Minyak } \\
\text { goreng }\end{array}$ & 13.000 & $1 \mathrm{~kg}$ \\
\hline \multirow[t]{7}{*}{2} & 2 & Tepung & 10.000 & $4 \mathrm{~kg}$ \\
\hline & & Telur & 2. 000 & 16 butir \\
\hline & & Gula & 15.000 & 16 sendok \\
\hline & & Kentang & 12.000 & $1,5 \mathrm{~kg}$ \\
\hline & & Margarin & 8.000 & 500 gram \\
\hline & & Garam & 1.000 & 6 sendok teh \\
\hline & & Farmipan & 2.000 & \\
\hline
\end{tabular}




\begin{tabular}{|c|c|c|c|c|}
\hline \multirow[t]{2}{*}{ No } & \multirow[t]{2}{*}{$\begin{array}{l}\text { Produksi } \\
\text { ke- }\end{array}$} & \multirow{2}{*}{$\begin{array}{l}\quad \text { Jumlah } \\
\text { Minyak } \\
\text { goreng }\end{array}$} & \multirow{2}{*}{$\begin{array}{l}\text { Harga Per Unit } \\
\quad \text { (Rp) } \\
13.000\end{array}$} & \multirow{2}{*}{$\begin{array}{l}\text { Jumlah Tahapan } \\
\text { Per Produksi } \\
1 \mathrm{~kg}\end{array}$} \\
\hline & & & & \\
\hline \multirow[t]{8}{*}{3} & 3 & Tepung & 10.000 & $2 \mathrm{~kg}$ \\
\hline & & Telur & 2. 000 & 6 butir \\
\hline & & Gula & 15.000 & 8 sendok \\
\hline & & Kentang & 12.000 & $1 \mathrm{~kg}$ \\
\hline & & Margarin & 8.000 & 300 gram \\
\hline & & Garam & 1.000 & 4 sendok the \\
\hline & & Farmipan & 2.000 & 3 sendok teh \\
\hline & & $\begin{array}{l}\text { Minyak } \\
\text { goreng }\end{array}$ & 13.000 & $1 \mathrm{~kg}$ \\
\hline \multirow[t]{8}{*}{4} & 4 & Tepung & 10.000 & $4,3 \mathrm{~kg}$ \\
\hline & & Telur & 2.000 & 18 butir \\
\hline & & Gula & 15.000 & 14 sendok \\
\hline & & Kentang & 12.000 & $2 \mathrm{~kg}$ \\
\hline & & Margarin & 8.000 & 600 gram \\
\hline & & Garam & 1.000 & 7 sendok teH \\
\hline & & Farmipan & 2.000 & \\
\hline & & $\begin{array}{l}\text { Minyak } \\
\text { goreng }\end{array}$ & 13.000 & $1,5 \mathrm{~kg}$ \\
\hline
\end{tabular}

Sumber: Hasil dari Penelitian

Dari data yang sudah diperoleh maka disusun sebuah tabel perhitungan di bawah ini. Berdasarkan data yang diperoleh dan berikut penjabaran cara perhitungannnya:

Tabel 6. Data perhitungan

\begin{tabular}{|c|c|c|c|c|c|c|c|c|c|c|c|c|}
\hline $\mathbf{N}$ & iT & iV & $\mathrm{TP} / \mathrm{Q}$ & MP & AP & TFC & TVC & TC & $A C$ & MC & AVC & AFC \\
\hline 1 & 1 & 8 & 100 & 0 & 4,710 & $\begin{array}{l}378.0 \\
00\end{array}$ & $\begin{array}{l}93.00 \\
0\end{array}$ & $\begin{array}{l}471.0 \\
00\end{array}$ & 4.71 & - & $\begin{array}{l}3,27 \\
0\end{array}$ & 930 \\
\hline 2 & 1 & 8 & 120 & 0 & 4,233 & $\begin{array}{l}378.0 \\
00\end{array}$ & $\begin{array}{l}130.0 \\
00\end{array}$ & $\begin{array}{l}508.0 \\
00\end{array}$ & 4,233 & 208 & $\begin{array}{l}3,27 \\
0\end{array}$ & $\begin{array}{l}1,08 \\
3\end{array}$ \\
\hline
\end{tabular}




\begin{tabular}{lllllllllllll}
\hline $\begin{array}{l}\mathbf{N} \\
\mathbf{0}\end{array}$ & iT & iV & TP/Q & MP & AP & TFC & TVC & TC & AC & MC & AVC & AFC \\
\hline 3 & 1 & 8 & 90 & 0 & 5,1222 & $\begin{array}{l}378.0 \\
00\end{array}$ & $\begin{array}{l}83.00 \\
0\end{array}$ & $\begin{array}{l}461.0 \\
00\end{array}$ & 5,122 & -642 & 3,27 & 922 \\
$\cdot$ & & & & & & & & & & \\
0 & & & & & \\
\hline 4 & 1 & 8 & 150 & 0 & 3,580 & 378.0 & 159.0 & 537.0 & 3,580 & - & 3,27 & 1,06 \\
$\cdot$ & & & & & & 00 & 00 & 00 & & 89.4 & 0 & 0 \\
& & & & & & & & & & 9 & & \\
\hline
\end{tabular}

Sumber: Hasil dari Penelitian

2. Hasil Pembahasan

Dari data yang telah di sampaikan diatas dapat kita simpulkan bahwasanya faktor yang mempengaruhi naik atau turunya suatu penawaran adalah faktor barang lain, tingkat tehnologi yang digunakan dalam proses pembuatan barang dan biaya faktor produksi. Karena produsen dapat mengambil keputusan mengenai seberapa banyak peralatan produksi dan jumlah tenaga kerja untuk memenuhi permintaan konsumen-konsumennya terhadap produk yang dihasilkan.

Untuk selanjutnya yaitu mengenai konsep ekonomi konvensional (kapitalis) produksi yang dimaksut adalah memeperoleh laba atau keuntungan sebanyak banyaknya berbeda dengan konsep ekonomi Islam yaitu memberikan maslahah yang maksimum bagi konsumen, dan di dalam konsep Islam boleh mengambil laba atau keuntungan selama masih dalam kaidah - kaidah Islam.

\section{Pasar}

Tabel 7. Data pasar

\begin{tabular}{|c|c|c|c|c|c|c|c|}
\hline $\begin{array}{l}\mathbf{N} \\
\mathbf{0}\end{array}$ & Jenis Pasar & Alamat & $\begin{array}{l}\text { Jml } \\
\text { Penj } \\
\text { ual }\end{array}$ & $\begin{array}{c}\text { Jumla } \\
\text { h } \\
\text { Pemb } \\
\text { eli }\end{array}$ & Akses Pasar & Pricing & Ket. \\
\hline 1. & $\begin{array}{l}\text { Persaingan } \\
\text { Sempurna }\end{array}$ & $\begin{array}{l}\text { Jln. Raya } \\
\text { Ponorogo- } \\
\text { Madiun } \\
\text { pasar, } \\
\text { krajan, } \\
\text { Bangunsari } \\
\text { Kec. } \\
\text { Dolopo, } \\
\text { Madiun, } \\
\text { Jawa Timur } \\
63174\end{array}$ & 100 & 230 & $\begin{array}{l}\text { Bebas untuk } \\
\text { membuka dan } \\
\text { menutup } \\
\text { pasar, banyak } \\
\text { penjual dan } \\
\text { pembeli, serta } \\
\text { bersifat } \\
\text { homogen. }\end{array}$ & $\begin{array}{l}\text { Harga } \\
\text { ditentukan } \\
\text { oleh } \\
\text { kekuatan } \\
\text { interaksi } \\
\text { penjual dan } \\
\text { pembeli. }\end{array}$ & $\begin{array}{l}\text { Tidak } \\
\text { memiliki } \\
\text { kemampu } \\
\text { an untuk } \\
\text { menentu } \\
\text { ka harga. }\end{array}$ \\
\hline
\end{tabular}




\begin{tabular}{|c|c|c|c|c|c|c|c|}
\hline $\begin{array}{l}\mathbf{N} \\
\mathbf{0}\end{array}$ & Jenis Pasar & Alamat & $\begin{array}{c}\text { Jml } \\
\text { Penj } \\
\text { ual }\end{array}$ & $\begin{array}{c}\text { Jumla } \\
\text { h } \\
\text { Pemb } \\
\text { eli }\end{array}$ & Akses Pasar & Pricing & Ket. \\
\hline 2. & $\begin{array}{l}\text { Persaingan } \\
\text { Tidak } \\
\text { Sempurna }\end{array}$ & $\begin{array}{l}\text { Jln. } \\
\text { Pahlawan, } \\
\text { Kartoharjo, } \\
\text { Kec. } \\
\text { Kartoharjo, } \\
\text { Kota } \\
\text { Madiun, } \\
\text { Jawa } \\
\text { Timur. }\end{array}$ & 1 & 3.000 & $\begin{array}{l}\text { Tidak memiliki } \\
\text { jumlah penjual } \\
\text { dan pembeli } \\
\text { yang seimbang } \\
\text { penjual baru } \\
\text { sulit untuk } \\
\text { memulai dan } \\
\text { bersifat } \\
\text { heterogen. }\end{array}$ & $\begin{array}{l}\text { Harga } \\
\text { ditentukan } \\
\text { oleh } \\
\text { penjual } \\
\text { dengan } \\
\text { bebas. }\end{array}$ & $\begin{array}{l}\text { Memiliki } \\
\text { hak untuk } \\
\text { menentu } \\
\text { kan } \\
\text { harga. }\end{array}$ \\
\hline
\end{tabular}

Sumber : Hasil dari Penelitian

2. Hasil wawancara

Tabel 8. Hasil wawancara

\begin{tabular}{|c|c|}
\hline Pertanyaan & Jawaban \\
\hline $\begin{array}{l}\text { Bagaimana mekanisme harga pada } \\
\text { pasar persaingan sempurna dan pasar } \\
\text { persaingan tidak sempurna? }\end{array}$ & $\begin{array}{l}\text { Untuk pasar persaingan sempurna itu } \\
\text { ditentukan oleh kekuatan interaksi antara } \\
\text { penjual dan pembeli yang berdasarkan } \\
\text { pada kekuatan penawaran dan } \\
\text { permintaan. Sedangkan dalam pasar } \\
\text { persaingan tidak sempurna harga itu } \\
\text { ditentukan oleh penjual. }\end{array}$ \\
\hline $\begin{array}{l}\text { Apa yang membedakan antara pasar } \\
\text { persaingan sempurna dan pasar } \\
\text { persaingan tidak sempurna? }\end{array}$ & $\begin{array}{l}\text { Pada pasar persaingan sempurna itu } \\
\text { banyak penjual dan pembeli. Sedangkan } \\
\text { pasar persaingan tidak sempurna } \\
\text { penjualnya hanya1-2 saja. }\end{array}$ \\
\hline $\begin{array}{l}\text { Bagaimana akses masuk pasar bagi } \\
\text { penjual baru? }\end{array}$ & $\begin{array}{l}\text { Pada pasar persaingan sempurna akan } \\
\text { lancar jika mempunyai ide, motivasi, } \\
\text { kreatifitas, dan ramah maka akan banyak } \\
\text { membeli jadi lebih mudah untuk mencari } \\
\text { pelanggan. Sedangkan dalam pasar } \\
\text { persaingan tidak sempurna itu tidak } \\
\text { mudah untuk menjalankannya karena } \\
\text { barang ini bersifat heterogen dan juga } \\
\text { menguasai penentuan harga produk yang } \\
\text { dijual belikan untuk pengambilan } \\
\text { keputusan. }\end{array}$ \\
\hline
\end{tabular}

Sumber : Hasil dari pembahasan 


\section{SIMPULAN}

Perilaku konsumen adalah tindakan yang langsung terlibat dalam mendapatkan, mengkonsumsi dan menghabiskan produk dan jasa, termasuk keputusan yang mendahului dan menyusul tindakan ini. Perilaku konsumen dapat mempengaruhi jumlah permintaan dan kebutuhan. Perilaku produsen adalah kegiatan pengaturan produksi sehingga produk yang dihasilkan bermutu tinggi sehingga bisa menghasilkan laba. Perilaku produsen ini dapat mempengaruhi jumlah produksi dan penawaran barang atau jasa perilaku pasar adalah pola kebiasaan pasar meliputi proses pengambilan keputusan serta kegiatan individual maupun organisasi terhadap produk tertentu. Dalam Islam ketiga perilaku ini harus di landasi sesuai ajaran Islam yaitu tauhid, adil, nubuwah, khalifah dan ma'ad. Hal ini bertujuan untuk mendatangkan manfaat dan kemaslahatan masyarakat serta mencapai berkah dari Allah swt. Sebagai umat Islam kita seharusnya menerapkan perliaku konsumen, produsen, dan pasar. Sesuai dengan syariat Islam agar kegoiatan yang kita lakukan tidak hanya untuk keuntungan dunia tetapi untuk mendapatkan keuntungan akhirat juga.

\section{DAFTAR PUSTAKA}

Adiwarman A. Karim.(2012).Ekonomi Mikro Islami.Jakarta.Rajawali Pers.

Ahman,Eeng dan Yana Rohmana.2009.Teori Ekonomi Mikro.Bandung.Universitas Pendidikan Indonesia.

Bilson Simamora.(2002).Panduan Riset Perilaku Konsumen.Jakarta.PT. Gramedia Pustaka Utama.

Choirul Huda.(2015).Ekonomi Islam.Semarang.CV. Karya Abadi Jaya.

Ibnu Khaldun,The Muqaddimah.(1967).English Edition Transl.London. Franz Rosenthal .

James F, Engel, et. Al.(1994).Perilaku Konsumen Jilid 1.Jakarta.Binarupa Aksara.

Lukman.(2006).Pengantar Teori Mikro Ekonomi.Jakarta.UIN Jakarta Press.

Manan.(1997).Teori dan Praktek Ekonomi Islam.Yogyakarta.Dana Bhakti primayasa.

Muhammad.(2004).Ekonomi Mikro dalam Perspektif Islam cet ke 1.Yogyakarta. BPFE Yogyakarta.Imam gunawan.(2013).Metode Penelitian Kualitatif teori dan Praktik.Jakarta.Bumi Aksara.

Muhammad dan Lukman Fauroni.(2002).Visi Al-Quran Tentang Etiak dan Bisnis. Jakarta.Salemba Diniyah. 
Rahardja, Prathama dan Mandala Manurung.2008.Pengantar Ilmu Ekonomi (Mikroekonomi \& Makroekonomi)edisi ketiga. Jakarta.Fakultas Ekonomi Universitas Indonesia.

Rochmawan, Laksono Tri. (2008). Pengantar Ekonomi Mikro. Semarang. Anindya.

Rozalinda.Ekonomi Islam: Teori dan Aplikasinya pada Aktivitas Ekonomi, Jakarta.PT Raja Grafindo Persada.

Sumarin.(2013).Ekonomi Islam.Yogyakarta.Graha Ilmu. 